\title{
Induction of Systemic Resistance by Bacillus subtilis Isolates against Fusarium Wilt of Chilli
}

\author{
K. Rajkumar ${ }^{1 *}$, M.K. Naik ${ }^{1}$, Y.S. Amaresh ${ }^{1}$ and G. Chennappa ${ }^{2}$ \\ ${ }^{1}$ Department of Plant Pathology, University of Agricultural Sciences, Raichur, India \\ ${ }^{2}$ Department of Processing and Food Engineering, University of Agricultural Sciences, \\ Raichur- 584104, India \\ *Corresponding author
}

\begin{tabular}{|c|c|}
\hline & B S T R A \\
\hline & \multirow{3}{*}{$\begin{array}{l}\text { Soil has enormous potential antagonistic mechanism, which have positive influence on } \\
\text { plant growth and health. Among the microbes, Bacillus subtilis an endospore forming, } \\
\text { gram positive bacteria, plays a major role in biocontrol and PGPR activities. Among the } \\
\text { different mechanisms of biocontrol, Induced systemic resistance is the one which induces } \\
\text { the resistance by activating the defence related enzymes and increasing the growth } \\
\text { parameters. The potential isolates of } B \text {. subtilis were studied for induction of systemic } \\
\text { resistance. Among them isolate, BS16 recorded highest germination }(94.25 \%) \text {, vigour } \\
\text { index }(1030) \text {, shoot length }(8.50 \mathrm{~cm}) \text { and root length }(4.8 \mathrm{~cm}) \text { compared to control. The } \\
\text { treatment BS } 16+\mathrm{FS} \text { recorded highest defence enzymes, peroxidise ( } 1.04 \text { change in } \\
\text { absorbance at } 470 \mathrm{~nm} / \mathrm{min} / \mathrm{mg} \text { protein), polyphenol oxidise }(0.79 \text { change in absorbance at } \\
420 \mathrm{~nm} / \mathrm{min} / \mathrm{mg} \text { protein) and Phenylalanine ammonia lyase (nmol trans-cinamic } \\
\text { acid } / \mathrm{hr} / \mathrm{mg} \text { protein) activity on the } 7^{\text {th }} \text { day after challenge inoculation, thereafter the } \\
\text { activity declined by } 9^{\text {th }} \text { day compared to control. B. subtilis is one of the potential isolate } \\
\text { which induces the systemic resistance in chilli against the Fusarium wilt. }\end{array}$} \\
\hline & \\
\hline & \\
\hline
\end{tabular}

\section{Introduction}

Soil has enormous potential antagonistic microorganisms which are helpful in reducing the pathogen population through different mode of actions such as competition for food and space (Martin, 1971, Lynch, 1983), mycoparasitism, antibiosis, production of PGPR compounds and production of enzymes (Janisiewicz et al., 2000). In recent years several microbes with potential biocontrol properties have come to light. Microbes such as bacteria, fungi, viruses, protozoa and nematodes that are known to produce an array of metabolites, form the basis for antimicrobial compounds. The microbial strains with good antimicrobial properties have been used in plant disease management.

Recently, a considerable attention has been given to some of the rhizobacteria which have positive influence on the plant growth and health. These are referred as Plant Growth Promoting Rhizobacteria (PGPR) (Schippers, 1992) such as Azatobacter, Pseudomonas, Azospirullum, Bacillus and Brukholderia, and 
some are members of the Enterobacteriacea. PGPR are known to control a wide array of phytopathogens like fungi, bacteria and nematodes. They multiply rapidly occupy all available niches, absorb nutrients and form biological screen around the root and prevents breeding, growth, invasion of harmful microorganisms (Timmusk et al., 2005; Haggag and Timmusk, 2008). These microbes are used as a biocontrol agents, bio fertilizers, bio pesticides and bio remediators because the PGPR are actively involved in production of phytoharmones, organic acids, siderophores, hydrolytic enzymes, antibiotics and compounds like $\mathrm{HCN}, \mathrm{NH}_{3} \mathrm{H}_{2} \mathrm{~S}$, fixation of atmospheric nitrogen, phosphate solubilisation and induction of systemic resistance.

The application of Plant Growth Promoting Rhizobacteria (PGPR) in controlling plant diseases is gaining significance. Bacillus subtilis are gram positive PGPR widely used in plant disease biocontrol. B. subtilis an endospore forming, gram positive bacteria, plays a major role in biocontrol and PGPR activities. ISR is a process of active resistance dependent on the host plants physical or chemical barriers activated by biotic or abiotic agents. The ISR stimuli were shown to be salicylic acid (De Mayer and Hofte, 1997), avirulent pathogens and non pathogens such as rhizobacteria and endophytes (Hallmann et al., 1997). Among PGPR microbes B. subtilis is one which play a major role in induction of resistance (Aliye et al., 2008) by production of defence related enzymes such as peroxidise, poly phenol oxidase and phynyl alanine ammonia lyase. Rhizobacteria mediated induced systemic resistance is phenotypically similar to the better known Systemic Acquired Resistance (SAR), the induced state that develops when plants successfully activate their defence mechanism in response to primary infection by a pathogen, notably when the latter induces a hypersensitive reaction through which it becomes limited in a local necrotic lesion of brown and desiccated tissue (Ryals et al., 1996). When these different signal transduction pathways are triggered simultaneously disease suppression is enhanced (Van Wees et al., 2000).

\section{Materials and Methods}

\section{Induced systemic resistance under in vitro by $B$. subtilis isolates}

The efficiency of isolates $B$. subtilis were studied in this experiment. The surface sterilised chilli seeds of variety Byadagi kaddi were soaked in suspension of different isolates of B. subtilis for four $\mathrm{h}$ followed by shade dried and the seeds were challenge inoculated with spore suspension of $1 \times 10^{6}$ conidia/ml of $F$. salani, wilt causing pathogen in chilli. The seeds treated with distilled water alone as a control and challenge inoculated with $F$. solani. 50 seeds were sown separately and seedling vigour was calculated after three weeks of sowing. The formula proposed by Abdulbaki and Anderson (1976) was used for calculating seedling vigour.

Seedling vigour $=($ Mean shoot length + Mean root length) $\mathrm{x}$ Percentage of germination

Induction of systemic resistance in vitro by $B$. subtilis isolates for short duration $\left(0-9^{\text {th }}\right.$ day)

Chilli seeds of cultivar Badagi kaddi were washed tho roughly using distilled water. Seven treatments were maintained. Treatments with five different isolates of $B$. subtilis and one each with $F$. solani and distilled water. Seven day old culture of $F$. solani was used to treat the seeds. About three $\mathrm{g}$ of talc based formulation of B. subtilis was used to treat the seeds, kept for four $\mathrm{h}$ and seeds were shade dried for 30 minutes and the seeds are challenge inoculated with spore suspension of 
F. solani and plated on free soaked blotter discs kept in Petri-dishes and equal distances (25 seeds per plate) and incubated at $25 \pm 2{ }^{\circ} \mathrm{C}$ moister was maintained in the Petri-dishes by regular watering up to final harvest. Seeds/seedlings were harvested at $0,1,3,5,7$ and 9 days after treatment. For each treatment three replications were maintained at each harvest three $\mathrm{g}$ of seeds was harvested from each treatment used to know the activity of PO, PPO and PAL.

\section{Peroxidase (PO) activity}

Assay of PO activity was carried out as per the procedure described by Hammerschmidt and Kuc (1982). The reaction mixture consisting of $2.5 \mathrm{ml}$ of a mixture containing 0.25 per cent $(\mathrm{v} / \mathrm{v})$ guaiacol in $0.01 \mathrm{M}$. sodium phosphate buffer, $\mathrm{pH} 6.0$ and $0.1 \mathrm{M}$ hydrogen peroxide. Enzyme extract $(0.1 \mathrm{ml})$ was added to initiate the reaction which was followed colorimetrically at $470 \mathrm{~nm}$. Crude enzyme preparations was diluted to give changes in absorbance at $470 \mathrm{~nm}$ of 0.1 to 0.2 absorbance units/min. Boiled enzyme was used as blank. Activity was expressed as the increase in absorbance at $470 \mathrm{~nm} \mathrm{~min} \mathrm{mg}^{-1}$ of protein.

\section{Polyphenol oxidase (PPO) activity}

A sample of one $\mathrm{g}$ was homogenized in $2 \mathrm{ml}$ of $0.1 \mathrm{M}$ sodium phosphate buffer $(\mathrm{pH} \mathrm{6.5)}$ at $4{ }^{\circ} \mathrm{C}$. The homogenate was centrifuged at $20,000 \mathrm{rpm}$ for $15 \mathrm{~min}$ at $4{ }^{\circ} \mathrm{C}$. The supernatant served as enzyme source and polyphenol oxidase activity was determined as per the procedure given by Mayer et al., (1965).

The reaction mixture consisted of $1.5 \mathrm{ml}$ of $0.1 \mathrm{M}$ sodium phosphate buffer $(\mathrm{pH}$ 6.5) and $200 \mu \mathrm{l}$ of the enzyme extract. To start the reaction, $200 \mu \mathrm{l}$ of $0.1 \mathrm{M}$ catechol will be added and the activity was expressed as change in absorbance $\mathrm{min}^{-1} \mathrm{mg}^{-1}$ of protein.

\section{Phenylalanine ammonia lyase (PAL) activity}

A plant sample of one $\mathrm{g}$ was homogenized in $3 \mathrm{ml}$ of ice cold $0.1 \mathrm{M}$ sodium borate buffer, $\mathrm{pH} \quad 7.0$, containing $1.4 \mathrm{mM}$ of 2mercaptoethanol and $50 \mathrm{mg}$ of insoluble polyvinyl pyrrolidene (PVP). The resulting extract was filtered through cheese cloth and the filtrate was centrifuged at 20,000 rpm for 15 min at $4{ }^{\circ} \mathrm{C}$ and the supernatant was used as the enzyme source. PAL activity was determined as the rate of conversion of $\mathrm{L}$ phenylalanine to trans-cinnamic acid at 290 nm. Sample containing $0.5 \mathrm{ml}$ of enzyme extract was incubated with $0.5 \mathrm{ml}$ of $0.1 \mathrm{M}$ borate buffer $\mathrm{pH} 8.8$ and $9.5 \mathrm{ml}$ of $12 \mathrm{mM} \mathrm{L}$ phenylalanine in the same buffer for $30 \mathrm{~min}$ at $30{ }^{\circ} \mathrm{C}$. The amount of trans-cinnamic acid synthesized was calculated (Dickerson et al, 1984).

\section{Results and Discussion}

\section{Induction of systemic resistance and plant growth promotion activities in chilli}

The bioagent $B$. subtilis isolates were tested under in vitro conditions by challenge inoculation with wilt causing pathogen of chilli ( $F$. solani). Per cent seed germination and vigour index were the parameters used for assessing induced systemic resistance. The $B$. subtilis isolate BS 16 recorded highest $(94.25$ $\%)$ seed germination, vigour index (1030), shoot length $(8.50 \mathrm{~cm})$ and root length $(4.8$ $\mathrm{cm}$ ) followed by BS30 with per cent seed germination of $(91.30 \%)$ vigour index (915) mean shoot length $(8.4 \mathrm{~cm})$ and mean root length $(4.8 \mathrm{~cm})$. Least per cent seed germination was 40 with vigour index of 267 , mean shoot length of $3.8 \mathrm{~cm}$ and mean root length of $3 \mathrm{~cm}$ was observed in case of $F$. solani alone inoculation. There was significant difference between BS16 and other isolates (Table 1). All the tested isolates were positive 
for growth parameters such as per cent seed germination, vigour index, mean shoot and root length and negative results for these parameters was observed in case of pathogen alone (FS) inoculation.

Anand et al., (2008) showed highest induction of resistance, higher seed germination of 96.5 per cent, mean shoot length of $9.00 \mathrm{~cm}$ and mean root length of $8.03 \mathrm{~cm}$, with vigour index of 1703 compared to uninoculated control (vigour index of 735) by Pf4 isolate. Increase in vigour of many crops has been demonstrated in some crops using bioagents. Sivamani and Gnanamanickam (1988) noticed that application of $P$. fluorescens gave better root growth and plant height in banana. Similarly, Bhatia et al., (2005) noticed that seed treatment of sunflower with $P$. fluorescens I and $P$. fluorescens II resulted in increased total root biomass in sunflower. Khanuchiya et al., (2012) concluded that the caster seeds were treated with pathogenic fungus as well as $P$. fluorescence, $P$. aeuroginosa and $B$. subtilis. The shoot and root length were measured as growth parameters after tenth day of the germination. $P$. fluorescence has shown the highest growth promoting effect, followed by $P$. aeuroginosa and least was in B. subtilis. The most positive response was observed with $P$. fluorescence in castor seedlings. Ramyabharathi and Raguchander, (2013) reported that, B. subtilis EPCO16 could promote the growth of tomato seedlings (vigour index, 2311.46) as compared to control.

Induction of systemic resistance in vitro by B. subtilis isolates for short duration $\left(0-9^{\text {th }}\right.$ day)

\section{Peroxidase activity (PO)}

The peroxidase activity was initially not seen on $0^{\text {th }}$ day and $1^{\text {st }}$ day after challenge inoculation but it started slowly from $3^{\text {rd }}$ day onwards increased gradually up to $7^{\text {th }}$ day thereafter again it started declining. The treatment BS16+FS showed highest PO activity (1.04 change in absorbance at 470 $\mathrm{nm} / \mathrm{min} / \mathrm{mg}$ protein) on the $7^{\text {th }}$ day after challenge inoculation and later $9^{\text {th }}$ day PO activity (0.98 change in absorbance at 470 $\mathrm{nm} / \mathrm{min} / \mathrm{mg}$ protein) decreases, which significantly differed in PO activity compared to all other treatments. The treatment FS (pathogen alone) showed lower values (0.76 change in absorbance at $470 \mathrm{~nm} / \mathrm{min} / \mathrm{mg}$ protein), compared to the $B$. subtilis treated plants. Least PO activity was noticed in uninoculated plants (0.65 change in absorbance at $470 \mathrm{~nm} / \mathrm{min} / \mathrm{mg}$ protein).

Peroxidise have been implicated in the regulation of plant cell elongation, phenol oxidation, polysaccharide cross-linking, IAA oxidation, cross linking of extension monomers, oxidation of hydroxyl-cinnamyl alcohols into free radical intermediates and wound healing (Vidhyasekaran et al., 1997). Plant root colonization by PGPR was associated with PO activity (Albert and Anderson, 1987).

Bradley et al., (1992) correlated an increased PO activity with resistance in many species including barley, cucurbits, cotton, tobacco, wheat and rice. These enzymes are involved in the polymerization of proteins and lignin or suberin precursor into plant cell wall, thus constructing a physical barrier that could prevent pathogen penetration of cell walls and movement through vessels. Seed treatment and seedling root dipping induced early and enhanced levels of PO in rice plants (Nayar, 1996; Radjacommare et al., 2002; Saravanakumar et al., 2008). These enzymes are also part of the response of plant defence to pathogens (Hammerschmidt and Kuc, 1995) and they may decrease the quality of these plants as host for insects (Duffey and Stout, 1996) (Table 2 and Fig. 1). 
Kavitha (2004) reported that the peroxidise activity was maximum on the fourth day after challenge inoculation in the turmeric rhizome but an increase in the activity was maximum on the fourth day after challenge inoculation in turmeric rhizome but an increase in the activity was observed up to sixth day after inoculation in case of turmeric leaves pretreated with consortia formulation of $P$. chlororaphis (PA23) and B. subtilis (9 CBE 4) which was challenged with $P$. aphanidermatum.

Among the treatment inoculation of pathogen followed by $P$. fluorescens + B. subtilis $(0.2$ $\%)$ sprayed plants recorded maximum accumulation of peroxidase of 0.170 absorbance / min / $\mathrm{g}$ of leaves on the 4th day after treatment with the mean value of 0.133 absorbance / $\mathrm{min} / \mathrm{g}$ followed to this treatment Pseudomonas alone sprayed plants also showed appreciable amount of peroxidase accumulation 0.170 absorbance/ $\mathrm{min} / \mathrm{g}$ of leaves on 4th day after treatment with the mean value of 0.132 absorbance/ min/ g. The untreated and uninoculated control viz water sprayed plants showed very minimum accumulation of peroxidase on 4th day after treatment (Ahila Devi et al., 2013).

\section{Polyphenol oxidase activity (PPO)}

PPO activity started on $3^{\text {rd }}$ day onwards and it reached its maximum on $7^{\text {th }}$ day after challenge inoculation. The treatment BS16+FS showed highest PPO activity (0.89 change in absorbance at $420 \mathrm{~nm} / \mathrm{min} / \mathrm{mg}$ protein) on the $7^{\text {th }}$ day after challenge inoculation and later on it started declining on the $9^{\text {th }}$ day with PPO activity (0.79 change in absorbance at $420 \mathrm{~nm} / \mathrm{min} / \mathrm{mg}$ protein) which significantly differed in PPO activity compared to all other treatments. The treatment FS (pathogen alone) ( 0.45 change in absorbance at $420 \mathrm{~nm} / \mathrm{min} / \mathrm{mg}$ protein), showed lower level of PPO activity compared to the B. subtilis treated plants. Least PPO activity was noticed in uninoculated (DW) ( 0.40 change in absorbance at $420 \mathrm{~nm} / \mathrm{min} / \mathrm{mg}$ protein) plants. PPO was catalyses the biosynthesis of oxidative phenols. It accumulates wounding in plants. Biochemical approaches to understand PPO function and regulation are difficult because the quinoid reaction products of PPO covalently modify and cross link the enzyme (Kavitha, 2004).

PPO usually accumulated upon wounding in plants, biochemical approaches to understand PPO function and regulation are difficult because the quinoid reaction products of PPO covalently modify and cross-link the enzyme. The increased activation of PPO could be detected in the cucumber leaf in the vicinity of lesions caused by some foliar pathogens. Moreover, PPO can be induced via. octadecanoid defence signal pathway (Constabel et al., 1995). Meena et al., (2000) observed increase in phenol content in groundnut plants treated with $P$. fluorescens which gave resistance to late leaf spot disease. Sivakumar and Sharma (2003) found increase in phenol when maize seeds were treated with $P$. fluorescens. In the present investigation, PPO activity was increased from $2^{\text {nd }}$ day after challenge inoculation, but maximum activity was recorded on the $4^{\text {th }}$ day after challenge inoculation with the pathogen. Ramamoorthy and Samiyappan (2001) reported that treatment of chilli plants with $P$. fluorescens challenge inoculated with $C$. capsici accelerated PPO activity (Table 3 ).

The increased activation of PPO could be detected in cucumber leaf in the vicinity of lesions caused by some foliar pathogens. Activation of PPO was stimulated by root application of $P$. corrugate 13 and $P$. aureofaciens in cucumber roots in response to infection by $P$. aphanidermatum and correlated in disease resistance (Chen et al., 2000). 
Mathiyazhagan (2003) observed that combined application of biocontrol agents as seed soaking and foliar spray on P. amarus recorded the maximum PPO activity on fourth day after challenge inoculation with the pathogen C. cassicola.

The poly phenol oxidase content was generally observed in all treatments from its 0 day of observation. Among the treatment pathogen followed by $P$. fluorescens+ $B$. subtilis $(0.2 \%)$ sprayed plants recorded maximum accumulation of poly phenol with
1.800 absorbance / $\mathrm{min} / \mathrm{g}$ of leaves on the 4 th day after treatment with the mean value of 0.181 absorbance $/ \mathrm{min} / \mathrm{g}$ followed to this treatment Pseudomonas alone sprayed plants also showed appreciable amount of poly phenol oxidase accumulation of 0.188 absorbance $/ \mathrm{min} / \mathrm{g}$ of leaves on 4th day after treatment with the mean value of 0.180 absorbance / $\mathrm{min} / \mathrm{g}$ untreated and uninoculated control viz, water sprayed plants showed very minimum accumulation of phenol on 4th day after treatment (Ahila Devi et al., 2013) (Fig. 2).

Table.1 Induction of systemic resistance in chilli by B. subtilis (BS) isolates challenge inoculated with $F$. solani

\begin{tabular}{|c|c|c|c|c|}
\hline Treatment & $\begin{array}{c}\text { Germination Per } \\
\text { cent }\end{array}$ & $\begin{array}{c}\text { Mean shoot } \\
\text { length }(\mathrm{cm})\end{array}$ & $\begin{array}{c}\text { Mean root } \\
\text { length }(\mathrm{cm})\end{array}$ & Vigour index \\
\hline BS5+F.S & $89.49(71.08) *$ & 6.81 & 5.4 & 867.88 \\
\hline BS7+F.S & $90.30(73.89)$ & 6.98 & 5.3 & 907.36 \\
\hline BS9+F.S & $89.53(71.12)$ & 6.53 & 4.8 & 805.78 \\
\hline BS16+F.S & $94.25(80.45)$ & 8.50 & 4.8 & 1069.98 \\
\hline BS30+F.S & $91.30(78.87)$ & 8.40 & 4.8 & 915.97 \\
\hline Inoculated $(\mathbf{F . S})$ & $40.00(39.23)$ & 3.80 & 3.0 & 266.76 \\
\hline Uninoculated & $87.00(77.47)$ & 4.80 & 4.2 & 697.23 \\
\hline S.Em \pm & $\mathbf{0 . 5 5}$ & $\mathbf{0 . 1 2}$ & $\mathbf{0 . 1 4}$ & $\mathbf{0 . 6 6}$ \\
\hline CD at 1 \% & $\mathbf{2 . 3 8}$ & $\mathbf{0 . 5 2}$ & $\mathbf{0 . 5 9}$ & $\mathbf{2 . 8 5}$ \\
\hline
\end{tabular}

Table.2 Induction of peroxidase activity in chilli by B. subtilis (BS) isolates challenge inoculated with $F$. solani (FS)

\begin{tabular}{|c|c|c|c|c|c|c|}
\hline \multirow{3}{*}{ Treatment } & \multicolumn{6}{|c|}{ Change in absorbance at $470 \mathrm{~nm} / \mathrm{min} / \mathrm{mg}$ protein } \\
\hline & \multicolumn{6}{|c|}{ Days after inoculation } \\
\hline & $\mathbf{0}$ & 1 & 3 & 5 & 7 & 9 \\
\hline BS5 \pm FS & - & - & 0.14 & 0.45 & 0.81 & 0.73 \\
\hline BS7 \pm FS & - & - & 0.26 & 0.59 & 0.89 & 0.81 \\
\hline BS9+FS & - & - & 0.22 & 0.49 & 0.86 & 0.79 \\
\hline BS16 + FS & - & - & 0.23 & 0.69 & 1.04 & 0.98 \\
\hline BS30 $\pm F S$ & - & - & 0.24 & 0.62 & 0.99 & 0.93 \\
\hline Inoculated (FS) & - & - & 0.14 & 0.43 & 0.76 & 0.69 \\
\hline Un inoculated & - & - & 0.12 & 0.39 & 0.65 & 0.60 \\
\hline S.Em \pm & - & - & 0.01 & 0.01 & 0.01 & 0.01 \\
\hline C.D at $1 \%$ & - & - & 0.02 & 0.03 & 0.05 & 0.04 \\
\hline
\end{tabular}


Table.3 Induction of polyphenol oxidase activity in chilli by B. subtilis (BS) isolates challenge inoculated with $F$. solani (FS)

\begin{tabular}{|c|c|c|c|c|c|c|}
\hline \multirow{2}{*}{ Treatments } & \multicolumn{6}{|c|}{ Change in absorbance at $420 \mathrm{~nm} / \mathrm{min} / \mathrm{mg}$ protein } \\
\cline { 2 - 7 } & \multicolumn{7}{|c|}{ Days after inoculation } \\
\cline { 2 - 7 } & $\mathbf{0}$ & $\mathbf{1}$ & $\mathbf{3}$ & $\mathbf{5}$ & $\mathbf{7}$ & $\mathbf{9}$ \\
\hline BS5 \pm FS & - & - & 0.08 & 0.38 & 0.48 & 0.41 \\
\hline BS7 \pm FS & - & - & 0.16 & 0.40 & 0.71 & 0.65 \\
\hline BS9+FS & - & - & 0.10 & 0.39 & 0.56 & 0.51 \\
\hline BS16+FS & - & - & 0.18 & 0.51 & 0.89 & 0.79 \\
\hline BS30+FS & - & - & 0.13 & 0.49 & 0.79 & 0.71 \\
\hline Inoculated & - & - & 0.06 & 0.34 & 0.45 & 0.40 \\
\hline Un inoculated & - & - & 0.05 & 0.20 & 0.40 & 0.34 \\
\hline S.Em \pm & - & - & $\mathbf{0 . 0 1}$ & $\mathbf{0 . 0 1}$ & $\mathbf{0 . 0 1}$ & $\mathbf{0 . 0 1}$ \\
\hline C.D at 1 \% & - & - & $\mathbf{0 . 0 4}$ & $\mathbf{0 . 0 3}$ & $\mathbf{0 . 0 3}$ & $\mathbf{0 . 0 2}$ \\
\hline
\end{tabular}

Table.4 Induction of phenylalanine ammonia lyase activity in chilli by B. subtilis $(\mathrm{BS})$ isolates challenge inoculated with $F$. solani (FS)

\begin{tabular}{|c|c|c|c|c|c|c|}
\hline \multirow{2}{*}{ Treatments } & \multicolumn{7}{|c|}{ nmol trans-cinamic acid /hr /mg protein } \\
\cline { 2 - 7 } & \multicolumn{7}{|c|}{ Days after inoculation } \\
\cline { 2 - 7 } & $\mathbf{0}$ & $\mathbf{1}$ & $\mathbf{3}$ & $\mathbf{5}$ & $\mathbf{7}$ & $\mathbf{9}$ \\
\hline BS5+FS & - & - & 14.20 & 22.80 & 71.80 & 65.77 \\
\hline BS7+FS & - & - & 14.67 & 20.57 & 78.47 & 74.13 \\
\hline BS9+FS & - & - & 13.84 & 21.57 & 74.47 & 67.67 \\
\hline BS16+FS & - & - & 16.67 & 28.83 & 80.45 & 78.53 \\
\hline BS30+FS & - & - & 15.27 & 26.60 & 78.50 & 74.71 \\
\hline Inoculated & - & - & 11.30 & 19.97 & 62.43 & 60.29 \\
\hline Un inoculated & - & - & 9.20 & 16.63 & 50.42 & 47.60 \\
\hline S.Em \pm & - & - & $\mathbf{0 . 0 5}$ & $\mathbf{0 . 1 3}$ & $\mathbf{0 . 2 2}$ & $\mathbf{0 . 3 7}$ \\
\hline C.D at 1 \% & - & - & $\mathbf{0 . 2 1}$ & $\mathbf{0 . 5 7}$ & $\mathbf{0 . 9 7}$ & $\mathbf{1 . 5 8}$ \\
\hline
\end{tabular}

\begin{tabular}{|l|l|l|}
\hline & Plate.2 Induction of systemic resistance by \\
isolates of $B$. subtilis (days)
\end{tabular}




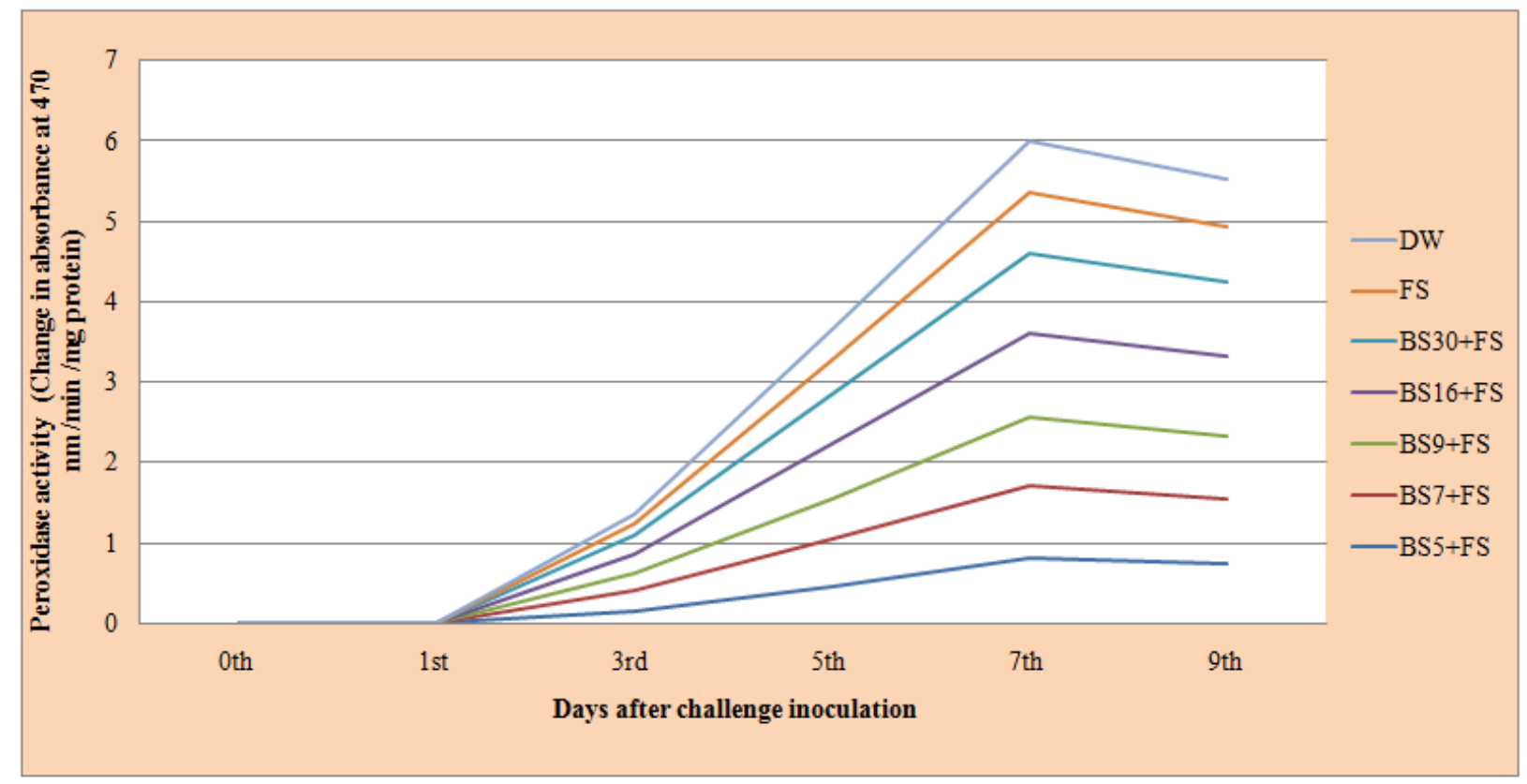

Fig.1 Induction of peroxidase activity in chilli by $B$. subtilis (BS) isolates challenge inoculated with $F$. solani (FS)

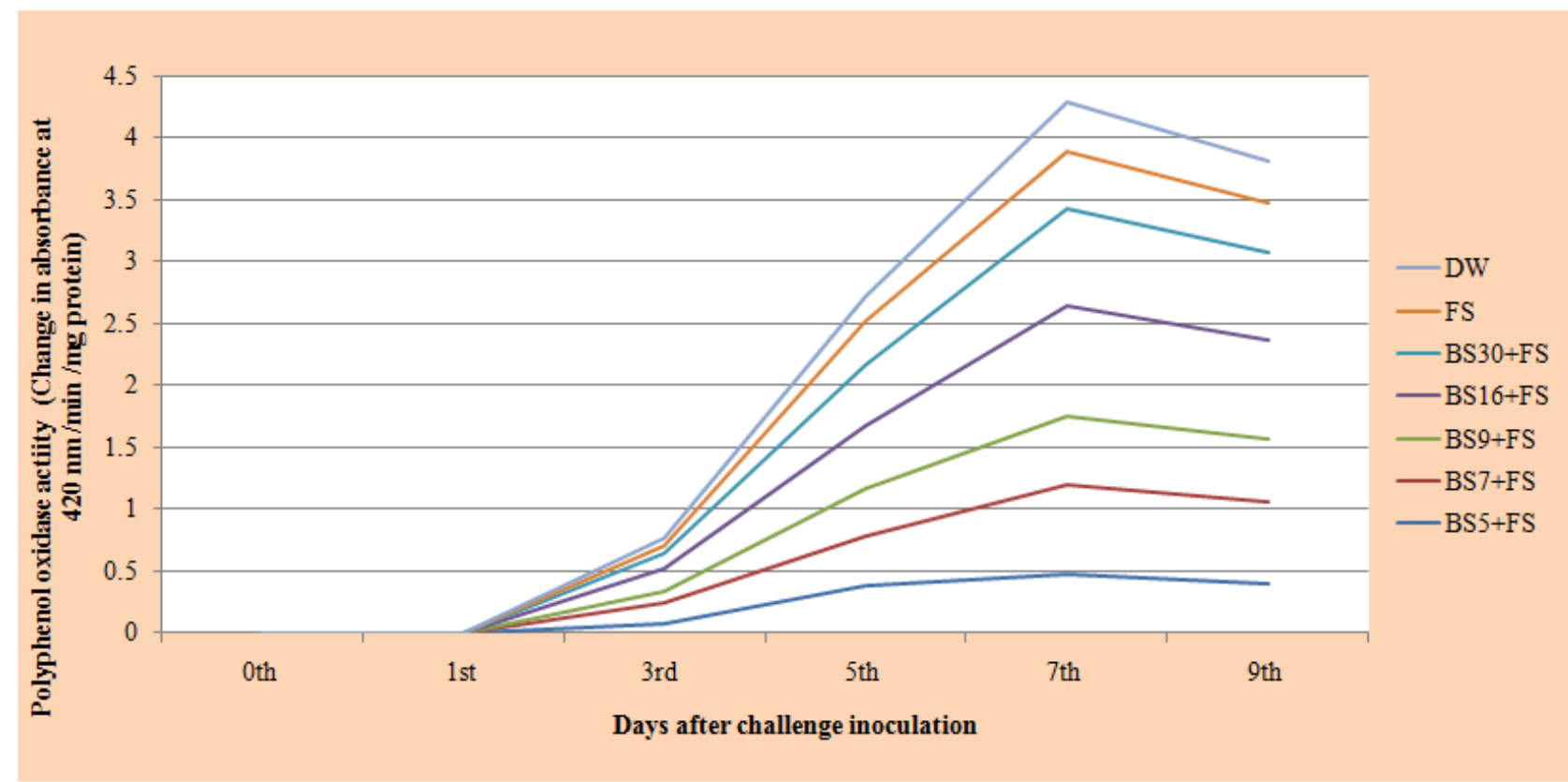

Fig.2 Induction of polyphenol oxidase activity in chilli by $B$. subtilis (BS) isolates challenge inoculated with $F$. solani (FS) 


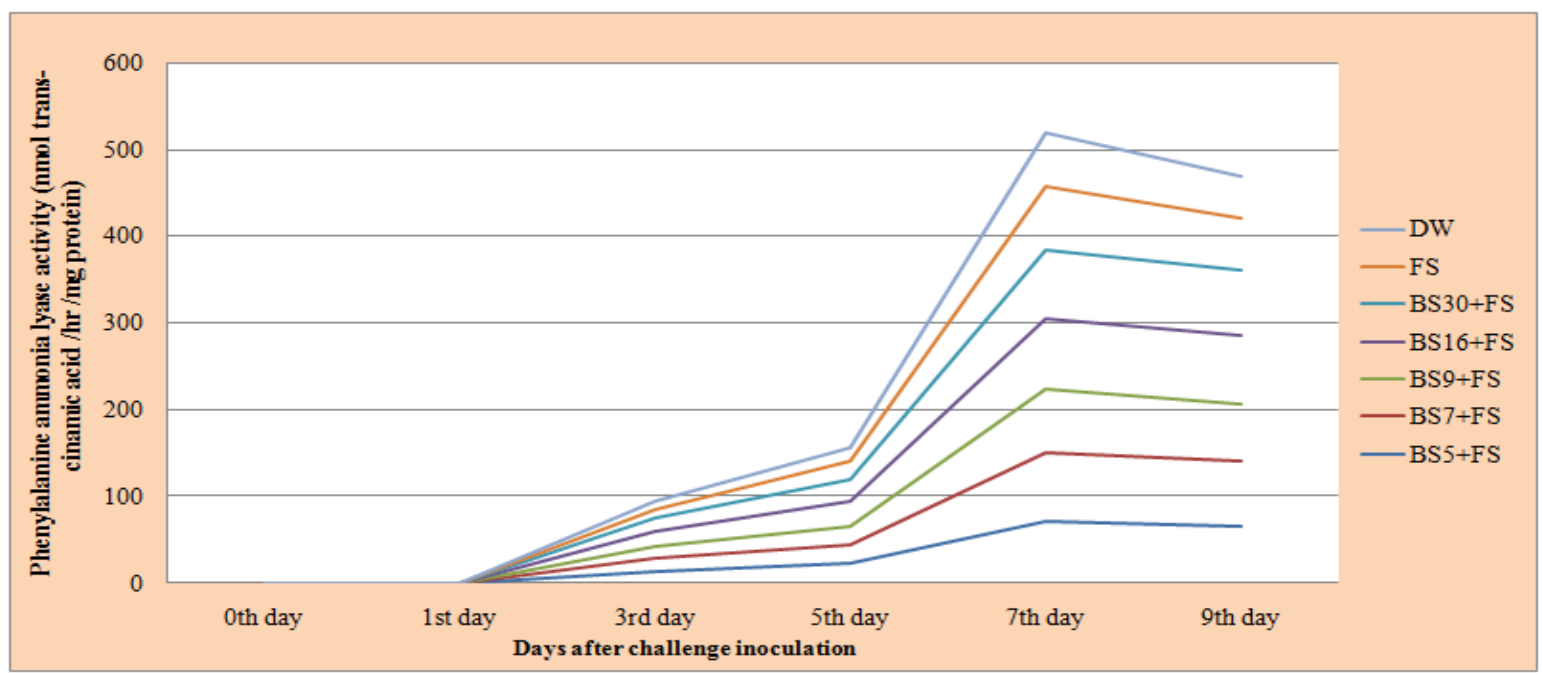

Fig.3 Induction of phenylalanine ammonia lyase activity in chilli by B. subtilis (BS) isolates challenge inoculated with $F$. solani (FS)

Phenylalanine ammonia lyase activity (PAL)

The PAL activity was observed maximum on $7^{\text {th }}$ day after challenge inoculation. The seedlings of BS16+FS recorded highest PAL activity $(80.45 \mathrm{nmol}$ trans-cinamic acid $/ \mathrm{hr} / \mathrm{mg}$ protein) on the $7^{\text {th }}$ day after challenge inoculation and later $9^{\text {th }}$ day onwards PAL activity $(78.53 \mathrm{nmol}$ trans-cinamic acid $/ \mathrm{hr} / \mathrm{mg}$ protein) started declining which significantly differed compared to all other treatments. The treatment FS (pathogen alone) showed (62.43 nmol trans-cinamic acid/hr/mg protein), lower PAL activity compared to the B. subtilis treated plants. Least PAL activity was noticed in uninoculated plants (50.42 nmol trans-cinamic acid/hr/mg protein).

PAL is the key enzyme in inducing synthesis of salicylic acid (SA), which induces systemic resistances in many plants. PAL plays an important role in the biosynthesis of phenolics and phytoalexins (Daayf et al., 1997).

The activation of the phenyl propanoid pathway in plants by environmental stimuli is one of the most universal biochemical stress responses known. PAL catalyzes the deamination of L-phenylalanine to transcinnamic acid, which is the first step in the biosynthesis of large class of plant natural products based on the phenylpropane skeleton, including lignin monomers as well as certain classes of phytoalexins. Induction of enzymes such as PAL and PO leading to the accumulation of phenolics and lignin can occur in response to insect and pathogen attack, exposure to oxidizing pollutants, mechanical stimulation and are thought to function in the resistance of plants ( $\mathrm{Li}$ et al., 1993). Seed and seedling root dipping with PGPR induced early and enhanced level of PAL in rice plants (Nayar, 1996) (Table 4 and Fig. 3).

The PAL content was generally observed in all treatments from its 0 day of observation. Among the treatment inoculation of pathogen followed by $P$. fluorescens along $B$. subtilis sprayed plants recorded maximum accumulation of PAL $60.0 \mathrm{nmol}$ transcinamic / acid / g of leaves on the 4th day after treatment with the mean value of $52.5 \mathrm{nmol}$ transcinamic / acid / $\mathrm{g}$ followed to this treatment Pseudomonas alone sprayed plants 
also showed appreciable amount of PAL accumulation $60.0 \mathrm{nmol}$ transcinamic/ acid / g of leaves on 4th day after treatment with mean value $52.2 \mathrm{nmol}$ transcinamic/ acid / g .the untreated and uninoculated control viz., water sprayed plants showed very minimum accumulation of phenol on 4th day after treatment(Ahila Devi et al., 2013).

Plants treated with Pseudomonas strains initially showed higher levels of PAL compared to control (Chen et al., 2000). Induction of PAL by fluorescent pseudomonads was reported in cucumber against $P$. aphanidermatum (Chen et al., 2000), tomato against $F$. oxysporum f. sp. lycopersici (Ramamoorthy et al., 2002). Phenyl propanoid metabolism starts with the conversion of L-phenylalanine into transcinnamic acid by the enzyme phenylalanine ammonia lyase (PAL) and supplies the precursors for flavanoid pigments, lignins and phytoalexins (Hahlbrock and Scheel, 1989; Massala et al., 1980).

In conclusions, the B. subtilis isolate, BS 16 recorded highest seed germination, vigour index, shoot length and root length and was significantly superior over all other treatments. The activity of defence enzymes showed higher activity on the $7^{\text {th }}$ day after challenge inoculation which was significantly different from all other treatments and thereafter the activity declined by $9^{\text {th }}$ day. $B$. subtilis is one of the potential isolate which induces the systemic resistnace in chilli against the Fusarium wilt.

\section{References}

Abdulbaki, A. A. and Anderson, J. D., 1976, Vigour determination in soybean seed by multiple criteria. Crop sci., 13: 630633.

Ahila Devi, P., Mohan, S. and Rajalakshmi, J., 2013, Induced defence response of sunflower to Alternaria helianthi by biocontrol consortia. J. Today's Biol. Sci. Res., 2(2): 29-43.

Albert, F. and Anderson, A. J., 1987, The effect of Pseudomonas putida colonization on root surface peroxidase. Pl. Physiol., 85: 535-541.

Aliye, A. N., Fininsa, B. C. and Hiskias, Y., 2008, Evaluation of rhizosphere bacterial antagonists for their potential to bioprotect potato (Solanum tuberosum) against bacterial wilt (Ralstonia solanacearum) Biol. Cont., 47: 282-288.

Anand, M., Naik, M. K., Ramegowda, G. and Devika Rani, G. S., 2010, Biocontrol and plant growth promotion activity of indigenous isolates of Pseudomonas fluorescens. J. Mycopathol. Res., 48(1): 45-50.

Bhatia, S., Dubey, R. C. and Maheswari, 2005, Enhancement of plant growth and suppression of collar rot of sunflower caused by Sclerotium rolfsii through fluorescent Pseudomonas. Indian Phytopathol., 58:17-24.

Bradley, D. J., Kjellborn, P. and Lamb, C., 1992, Elicitor and wound induced oxidative cross-linking of a plant cell wall proline-rich protein: A novel, rapid defence response. Cell, 70: 21-30.

Chen, C., Belanger, R. R., Benhameu, N. and Paulitz, T. C., 2000, Defence enzymes induced in cucumber roots by treatment with plant growth promoting rhizobacteria. Physiol. Mol. Pl. Pathol., 56: $13-23$.

Constabel, C. P., Bergery, D. R. and Ryan, C. A., 1995, Systemin activates synthesis of wound-inducible tomato leaf polyphenol oxidase via the octadecanoid defence signalling pathways. Proc. Natl. Acad. Sci. USA, 92: 407-412.

Daayf, F., Bel-Rhlid, R. and Bekabger, R. R., 1997, Methyl ester of p-coumaric acid: a phytoalexin like compound from long 
english cucumber leaves. J. Chem. Ecol., 29:1517-1526.

De Meyer G. and Hofte, M., 1997, Salicylic acid produced by the rhizobacterium Pseudomonas aeuroginosa 7NSK2 induces resistance to leaf infection by Botrytis cinerea on bean, Phytopathol., 87(6) :593.

Dickerson, D. P., Pascholati, S. F., Hagerman, A. E., Butler, L. G. and Niholson, R. L., 1984, Phenylalanine ammonia lyase and hydroxyl cinnamate $\mathrm{CoA}$ ligase in maize mesocotyls inoculated with Helminthosporium maydis or Helminthosporium carbonum. Physiol. Pl. Pathol., 25(2): 111-123.

Duffey, S. S. and Stout, M. J., 1996, Antinutritive and toxic components of plant defence against insect. Arch. Insect Biochem. Physiol., 32: 3-37.

Hahlbrock, K. and Schee, D., 1989, Physiology and molecular biology of phenylpropanoid metabolism. Ann. Rev. Pl. Physiol.40: 347-367.

Timmusk, S., Grantcharova, N. and Wagner, E. G. H., 2005, Paenibacillus polymyxa invades plant roots and forms biofilms. Appl. Environ. Microbiol., 11: 72927300.

Martin, J. K., 1971, 14C labelled material leached from the rhizosphere of plants supplied with $14 \mathrm{CO}_{2}$. Aust. J. Biol. Sci., 24: 1131-1142.

Janisiewicz, N., Frazier, K., Judia, H. and Sumathy, V., 2000, Isolation and characterization of Bacillus subtilis isolated from soil. Afric. J. Biotec., 17(49): 36-44.

Haggag, W. M. and Timmusk, S., 2008, Colonization of peanut roots by biofilmforming Paenibacillus polymyxa initiates biocontrol against crown rot disease. J. Applied Microbiol. 104: 961969.

Schippers, B., 1992, Prospects for management of natural suppressiveness to control soilborne pathogenes. In: biological control of plant diseases, progress and challenges for the future. Life Sciences. Tjamos, E. C., Papavizas, G. C. and Cook, R. J. (eds.). Plenum Press, New York, USA. 230: 21-34.

Hallmann , J. R., Rodríguez-Kábana, J. W., Kloepper., 1997, Chitin-mediated changes in bacterial communities of the soil, rhizosphere and within roots of cotton in relation to nematode control. Soil Biology and Biochemistry, 31: 551.

Hammerschmidt, R. and Kuc, J., 1995, Induced resistance to disease in plants. Kluwer Academic Publishers, Dordrecht, The Netherlands., pp 182.

Kavitha, K., 2004, Molecular and biochemical approaches for the selection of biocontrol agents for the eco-friendly management of turmeric rhizome rot. Ph. D Thesis, Tamil Nadu Agric. Univ., Coimbatore (India).

Khanuchiya, S., Parabia, F. M., Patel, M., Patel, V., Patel, K. and Gami, B., 2012, Effect of Pseudomonas fluorescence, $P$. aeruginosa and Bacillus subtilis as biocontrol agent for crop protection. $J$. Microbiol., 1(1): 52-59.

Li, L., Qu, R., Kochko, A., Fauquet, C. and Beachy, R. N., 1993, An improved rice transformation system using the biolistic method. Pl. Cell Rep., 12: 250-255.

Massala, R., Legrand, M. and Fritig, B., 1980, Effect of aminooxyacetate a competitive inhibitor of phenylalanine ammonia lyase, on the hypersensitive resistance of tobacco to tobacco mosaic virus. Physiol. Pl. Pathol., 16: 213-226.

Mathiyazhagan, S., 2003, Studies on the soil borne diseases of Phyllanthus amarus (Scham and Thom) and their management. M. Sc. (Agri.) Thesis, Tamil Nadu Agric. Unvi., Coimbatore (India).

Mayer, A. M., Harel, E. and Shaul, R. B., 1965, Assay of catechol oxidase a 
critical comparison of methods. Phytochemistry, 5: 783-789.

Meena, B., Marimuthu, T. and Velazhan, R., 2000, Pseudomonas fluorescens mediated systemic resistance against late leaf spot of groundnut. J. Mycol. Plant Pathol., 30: 151-158.

Nayar, K., 1996, Development and evaluation of a biopesticides formulation for bio control of foliar disease of rice. $P h . D$ Thesis, Tamil Nadu Agric. Univ., Coimbatore (Indaia).

Radjacommar, R., Nandakumar, R., Kandan, A., Suresh, S., Bharathi, M., Raguchander, T. and Samiyappan, R., 2002, Pseudomonas fluorescens based bioformulation for the management of sheath blight and leaf folder in rice. Crop Protectss., 21: 671-677.

Ramamoorthy ,V., Raguchander, T. and Samiyappan, R., 2002, Induction of defense-related proteins in tomato roots treated with Pseudomonas fluorescens Pf1 and Fusarium oxysporum f.sp. lycopersici. Plant and Soil, 239: 55-68.

Ramamoorthy, V and Samiyappan, R. 2001. Induction of defence related genes in Pseudomonas fluorescens treated chilli plants in response to infection by Colletotrichum capsici. J. Mycol. Pl. Pathol., 31:146-155.

Ramyabharathi, S. A. and Raguchander, T., 2013, Induction of defence enzymes and proteins in tomato plants by Bacillus subtilis EPCO16 against Fusarium oxysporum $f$. sp. lycopersici. Madra. Agric. J., 100(2): 126-130.
Ryals, J. A., Neuenschwander, U. H., Willits, M. G., Molina, A., Steiner, H., Hunt, M. D., 1996, Systemic acquired resistance. Plant Cell 8: 1809-1819.

Saravanakumar, D. 2002, Rhizoctonia induced systemic resistance against biotroph (Exobasidium vexans) and necrotroph ( Macrophomina phaseolina ) pathogens in tea and greengram. $M$. Sci. (Agri.) Thesis, Tamil Nadu Agric. Univ., Coimbatore (India).

Sivakumar, G. and Sharma, R. C. 2003, Induced biochemical changes due to seed bacterization by Pseudomonas fluorescens in maize plants. Indian Phytopathol., 56: 134-137.

Sivamani, E. and Gnanamanickam, S. S., 1988, Biological control of Fusarium oxysporum f.sp. cubense in banana by inoculation with Pseudomonas fluorescens. Plant soil, 10: 3-9.

Van Wees, S. M., De Swart, E. A. M., Van Pelt, J. A., Van Loon, L. C., Pieterse, C. M. J., 2000, Enhancement of induced disease resistance by simultaneous activation of salicylate and jasmonatedependent defence pathways in Arabidopsis thaliana. Proc. Natl. Acad. Sci. USA, 97: 8711-8716.

Vidhyasekaran, P., Rabindran, R., Muthamilan, M. B., Nayar, K.B., Rajappan, K., Subramanian, $\mathrm{N}$ and Vasumathi K. 1997. Development of powder formulation of Pseudomonas fluorescens for control of rice blast. Plant Pathol., 46: 291-297.

\section{How to cite this article:}

Rajkumar, K., M.K. Naik, Y.S. Amaresh and Chennappa, G. 2018. Induction of Systemic Resistance by Bacillus subtilis isolates against Fusarium wilt of chilli. Int.J.Curr.Microbiol.App.Sci. 7(07): 2669-2680. doi: https://doi.org/10.20546/ijcmas.2018.707.313 